\title{
Current Biomedical Applications of 3D Printing and Additive Manufacturing
}

\author{
Pouyan Ahangar ${ }^{1}$, Megan E Cooke ${ }^{1}\left(\mathbb{D}\right.$, Michael H Weber ${ }^{1,2}$ and Derek H Rosenzweig ${ }^{1,2, *(D)}$ \\ 1 Department of Surgery, McGill University, Montreal, QC H3G 1A4, Canada; \\ pouyan.ahangar@mail.mcgill.ca (P.A.); megan.cooke@mail.mcgill.ca (M.E.C.); \\ michael.weber@hotmail.com (M.H.W.) \\ 2 Injury, Repair and Recovery Program, Research Institute of McGill University Health Centre, \\ Montreal, QC H3H 2R9, Canada \\ * Correspondence: derek.rosenzweig@mcgill.ca
}

Received: 16 March 2019; Accepted: 17 April 2019; Published: 25 April 2019

\begin{abstract}
Additive manufacturing (AM) has emerged over the past four decades as a cost-effective, on-demand modality for fabrication of geometrically complex objects. The ability to design and print virtually any object shape using a diverse array of materials, such as metals, polymers, ceramics and bioinks, has allowed for the adoption of this technology for biomedical applications in both research and clinical settings. Current advancements in tissue engineering and regeneration, therapeutic delivery, medical device fabrication and operative management planning ensure that AM will continue to play an increasingly important role in the future of healthcare. In this review, we outline current biomedical applications of common AM techniques and materials.
\end{abstract}

Keywords: 3D printing; additive manufacturing; rapid prototyping; tissue engineering; bioprinting; biomedical devices; regenerative medicine

\section{Introduction}

Conventional manufacturing consists of formative (molds) or subtractive (machining) techniques that require multiple steps and costly infrastructure, which limits capability for timely implementation of modifications to the final product [1]. Furthermore, these conventional techniques do not allow for intricate and complex geometries that are often required in biomedical engineering applications [1]. $3 \mathrm{D}$ printing, or additive manufacturing (AM), however, has emerged over the past four decades as a robust tool for fabricating geometrically complex objects in a cost-effective and timely manner [1-3]. Developed in the 1980s, the core concept of 3D printing involves layered deposition of material in three-dimensional space guided by a computer-generated model [4]. This allows for the creation of very complex designs that would be extremely difficult or even impossible to produce using conventional manufacturing techniques, which has resulted in its increased adoption by various industries [1]. Its role in healthcare is becoming increasingly important through its utilization in therapeutic delivery [5-7], surgical planning [8], implant design [9] and tissue engineering [10-12]. A unique but rapidly growing application of AM is bioprinting, which allows for the seeding of cells in a spatially defined manner in 3D space [13]. This enables the production of in vitro models for drug screening and disease modeling as well as biofabrication of implantable tissues such as skin [14], cartilage [15] or bone [16]. In this review, we will outline common AM fabrication methods, biomedically relevant printing materials and their use in healthcare applications. 


\section{Types of 3D Printing for Biomedical Applications}

Since the 1980s, diverse techniques for AM have been developed for layered printing of different materials. There are currently seven different established techniques for AM as outlined by the ISO/ASTM 52900 standard [17], and summarized comparisons of the techniques are outlined in Figure 1 and Table 1. Below, we briefly describe each process.

\subsection{Powder-Based Printing}

The two techniques below share the use of a powder bed as the base material for their constructs. However, they modify the powder in different ways to achieve a cohesive structure.

- Binder Jetting-This technique involves the jetting of binding material droplets over a powder bed. Once the binder has been sprayed over the powder bed, a fresh layer of powder is spread onto the bed and the next layer of binder is applied $[17,18]$.

- Powder Bed Fusion-In this technique, the powder is a material that can be melted using lasers. Once a layer of powder is molten, a new layer of powder is deposited on top and the process repeats $[17,19]$.

\subsection{Material Deposition}

These techniques utilize nozzles to deposit the printing material in layers.

- Direct Energy Deposition-In this technique, a nozzle deposits a continuous stream of metal onto the print surface, and a thermal energy source, such as laser, melts it continuously, layer by layer $[17,20]$.

- Material Extrusion-The printing material for this technique is thermoplastics, which are melted to a semi-liquid state and deposited continuously on the printing bed in layers. Binding of the layers is achieved due to the semi-liquid consistency of the plastic layers, causing them to fuse before curing in ambient temperature $[17,21]$. This technique can be used with pastes and hydrogels for co-printing with living cells.

- Material Jetting (MJ) - This technique utilizes jets to spray a layer of liquid resin while simultaneously curing the layer with UV light before printing the next layer [17,22].

- Bioprinting-This term encompasses the utilization of different AM technologies to 3D print living cells, and is not considered a specific AM technique on its own. The basic principle consists of the deposition of cells suspended in bioink by nozzle-based techniques, such as material extrusion or jetting, as outlined above, or laser-assisted nozzle-free techniques. Laser-assisted bioprinting involves forward transfer of droplets of cells suspended in bioink, focusing a laser on a membrane that is coated with cell-containing bioink on the side of the membrane facing the printing surface [23]. The advantage of this technique is the decreased shear stress on cells due to an absence of an orifice, and the microscopic resolution it achieves [24]. A further technique is inkjet or drop-on-demand (DOD) printing, where picolitre-volume droplets of cell-containing bioink are deposited with very high precision to coalesce into fibers. These are then crosslinked before subsequent layers are deposited, to produce a 3D structure $[25,26]$. Due to the very small volume of the droplets, sub-100 $\mu \mathrm{m}$ resolution can be achieved [27].

\subsection{Liquid Reservoir}

- Stereolithography (SLA) - The print bed is lowered into a vat containing a liquid photopolymer resin, and either UV or visible light is concentrated on the resin-bed interface to solidify the resin [4]. With every exposure to light, the bed containing the polymerized layer is lifted out of the resin and dipped back in to repeat the process $[4,17]$. 


\subsection{Sheets of Material}

- Sheet Lamination - In this process, sheets of material (paper, plastic, metal) are cut either with a laser or a blade, with each sheet representing a slice of the computer-aided design (CAD) model. After all sheets are cut, they are stacked and bound using a binder, and the cut sections are removed, revealing the three-dimensional inner design $[17,28]$.

\subsection{Nanofabrication}

Nanofabrication is the process of constructing structures less than $100 \mathrm{~nm}$ in size, making the suitable for use in a variety of fields including electronics and medicine. Despite not being recognized as a conventional AM technique, nanofabrication methods can employ many of the same principles. The manufacturing process for nanofabrication can be divided into two categories [29]. A "top-down" approach revolves around deconstructing a larger material to form the desired nanostructure, akin to carving a statue out of a block of stone and other traditional machining methods [29]. This principle requires complicated and expensive steps, offering little flexibility for modification. There is limited reproducibility of the nanostructures created through the "top-down" approach due to uncontrollable variability in the manufacturing process [29]. The second category of nanofabrication involves a "bottom-up" approach, where building blocks such as atoms or molecules either self-assemble or are "printed" to create a nanostructure [29]. This in turn can lead to structures with atomic resolution. The "bottom-up" approach is additive in nature, similar to most other AM techniques. There are endless applications of nanofabrication in biomedicine and tissue engineering, including (but not limited to): preserving immunogenicity of compounds in vaccines; minimizing transplant rejection through immuno-isolation; creation of biomaterials with unique mechanical and biological properties; drug sequestration and delivery; and circulating toxin and waste binders [30]. 

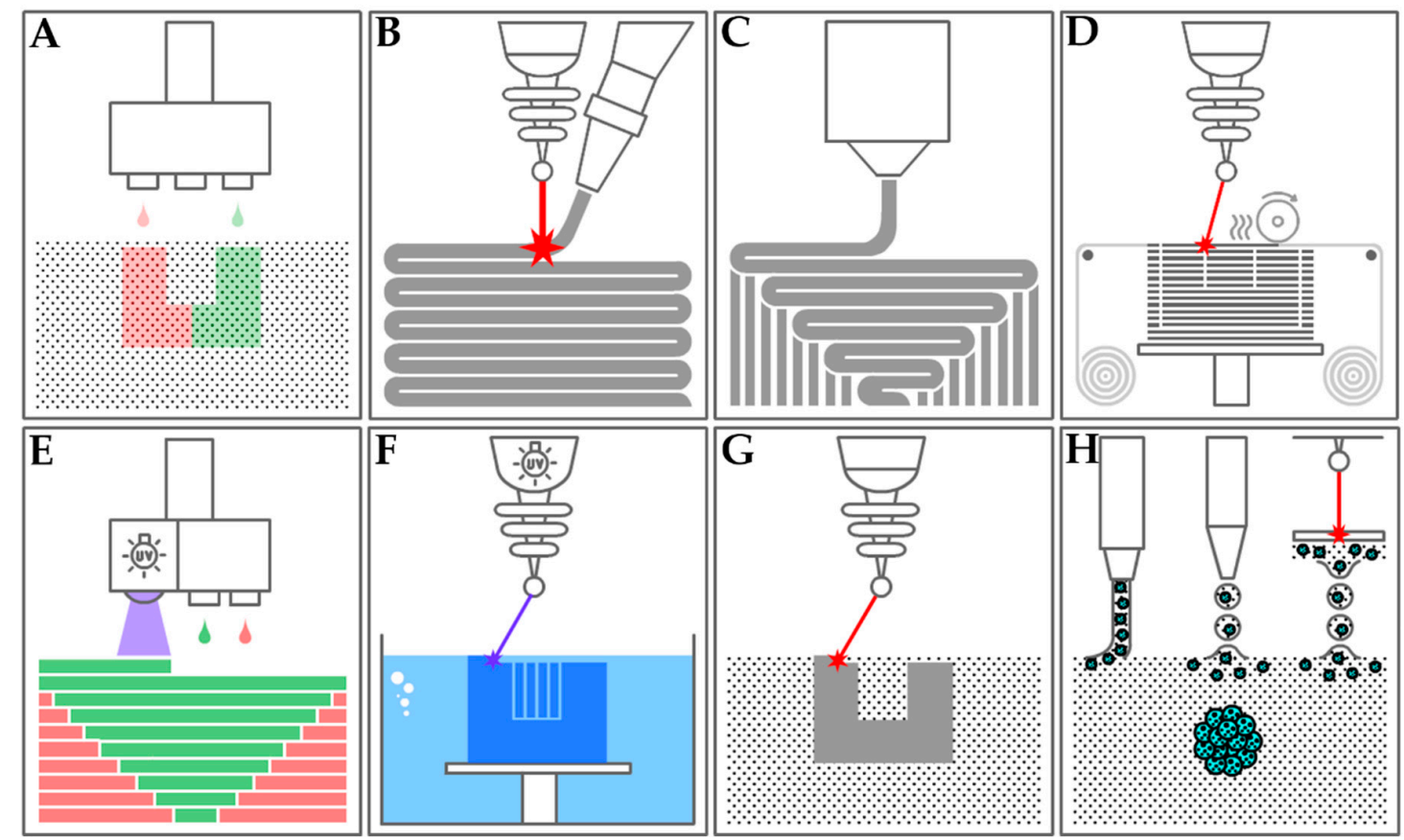

Figure 1. Types of additive manufacturing (AM). (A) Binder jetting-a liquid binder is jetted over a precise region of powder, additional powder is placed on top and the process repeats. (B) Directed energy deposition-a laser is used to melt metal as it is extruded from a nozzle. (C) Material extrusion-molten thermoplastics are dispended through a nozzle and cooled quickly on the print bed. (D) Sheet lamination-a sheet of material is cut to size with a blade or laser, the next sheet with adhesive is then added and heat is applied to adhere the layers before the second layer is cut to shape (E) Material jetting (MJ) — a layer of liquid resin is sprayed and then cured (often with UV light) before proceeding to the next layer. (F) Stereolithography - the print bed is lowered by a one-layer distance into a vat of liquid resin, which is then UV-cured; the print bed continues to move through the resin one layer at a time. (G) Powder bed fusion-a layer of powder (often metal) is spread over the print bed before being molten using a laser and formed into a layer. The print bed moves down, the next layer of powder is spread over the solidified layer and the process repeats. (H) Extrusion bioprinting (left)—similar to material extrusion, a bioink (mixture of cells and carrier material) is extruded from a nozzle or needle layer-by-layer before crosslinking or curing. Inkjet bioprinting (center) - picoliter-sized droplets of bioink are deposited onto the print bed and allowed to coalesce into fibers. Laser-assisted bioprinting (right) — a laser pulse causes small droplets of bioink to be dropped from a surface into defined geometries. *All figures are designed and created by the authors. 
Table 1. Types of Additive Manufacturing.

\begin{tabular}{|c|c|c|c|c|c|}
\hline Printing Technique & Material & Resolution & Biomedical Applications & Advantage & Disadvantage \\
\hline Binder Jetting & $\begin{array}{c}\text { Sand } \\
\text { Metal powder }\end{array}$ & $50-400 \mu \mathrm{m}$ & $\begin{array}{l}\text { Degradable (Fe-based alloys) } \\
\text { metallic implants [31]. Generally } \\
\text { used for hard, mineralized tissues }\end{array}$ & $\begin{array}{l}\text { Low cost, fast, color printing, no } \\
\text { support structure needed, large } \\
\text { objects }\end{array}$ & $\begin{array}{l}\text { Low strength, requires post-processing, } \\
\text { powders pose a respiratory hazard }\end{array}$ \\
\hline $\begin{array}{l}\text { Directed Energy } \\
\text { Deposition }\end{array}$ & $\begin{array}{l}\text { Metal } \\
\text { Nylon }\end{array}$ & $250-500 \mu \mathrm{m}$ & Limited use in medical applications & $\begin{array}{l}\text { Fast, composite materials, can } \\
\text { patch defects on existing objects }\end{array}$ & $\begin{array}{c}\text { Expensive, slow, low resolution, requires } \\
\text { post-process machining }\end{array}$ \\
\hline $\begin{array}{l}\text { Material Extrusion } \\
\quad\left(\mathrm{FDM}^{1}\right)\end{array}$ & $\begin{array}{c}\text { Hydrogels } \\
\text { Thermoplastics } \\
\text { Ceramics } \\
\text { Bioinks }\end{array}$ & $100-200 \mu \mathrm{m}$ & $\begin{array}{l}\text { Bioprinting of scaffolds for cell } \\
\text { culture, tissue and organ } \\
\text { development (soft tissues) [32] } \\
\text { Production of rigid and soft } \\
\text { anatomical models for surgical } \\
\text { planning }\end{array}$ & $\begin{array}{c}\text { Color, low cost, accessible, } \\
\text { composite materials, open source } \\
\text { designs }\end{array}$ & $\begin{array}{l}\text { Slow, anisotropy, lower resolution, } \\
\text { nozzles impart high shear forces on cells }\end{array}$ \\
\hline $\begin{array}{l}\text { Material Jetting/Inkjet } \\
\left(\mathrm{MJ}^{2}, \mathrm{DOD}^{3}\right)\end{array}$ & $\begin{array}{l}\text { Photopolymer } \\
\text { Bioinks }\end{array}$ & $20-100 \mu \mathrm{m}$ & $\begin{array}{l}\text { Bioprinting of scaffolds for cell } \\
\text { culture, tissue and organ } \\
\text { development (soft tissues) [33] }\end{array}$ & Good resolution and cell viability & Slow, material waste \\
\hline $\begin{array}{c}\text { Powder Bed } \\
\text { Fusion } \\
\left(\mathrm{SLS}^{4}, \mathrm{DMLS}^{5} / \mathrm{SLM}^{6},\right. \\
\left.\mathrm{EBM}^{7}\right)\end{array}$ & $\begin{array}{l}\text { Thermoplastics } \\
\text { Metal Powder } \\
\text { Ceramics }\end{array}$ & $100-200 \mu \mathrm{m}$ & $\begin{array}{c}\text { Metallic implants; dental, } \\
\text { craniofacial and orthopedic [34] } \\
\text { Temporary and degradable rigid } \\
\text { implants [35] }\end{array}$ & Strong, fast, no solvents required & $\begin{array}{l}\text { Most expensive, medium resolution, } \\
\text { post-processing required }\end{array}$ \\
\hline Sheet Lamination & $\begin{array}{l}\text { Paper } \\
\text { Ceramics } \\
\text { Metal }\end{array}$ & $\sim 1 \mathrm{~mm}$ & Macroscopic anatomical models & $\begin{array}{l}\text { Low cost, composite materials, no } \\
\text { support structure needed }\end{array}$ & $\begin{array}{l}\text { Slow, lots of material wasted, } \\
\text { delamination }\end{array}$ \\
\hline $\begin{array}{l}\text { Stereolithography } \\
\left(\text { (SLA }^{8}, \text { DLP }^{9}\right)\end{array}$ & $\begin{array}{l}\text { Photopolymer } \\
\text { Bio-resin }\end{array}$ & $1.2-200 \mu \mathrm{m}$ & $\begin{array}{l}\text { Bioprinting of scaffolds for cell } \\
\text { culture, tissue and organ } \\
\text { development, can be used for both } \\
\text { soft and hard tissues [36] }\end{array}$ & $\begin{array}{l}\text { High resolution, fast, very good cell } \\
\text { viability, nozzle free }\end{array}$ & $\begin{array}{l}\text { Raw material toxicity, limited material } \\
\text { selection, possible harm to DNA by UV }\end{array}$ \\
\hline Spheroid assembly & $\begin{array}{l}\text { Bioink } \\
\text { Organoids }\end{array}$ & $100-200 \mu \mathrm{m}$ & $\begin{array}{l}\text { Tissue and organ development, soft } \\
\text { tissues [37] }\end{array}$ & $\begin{array}{l}\text { Biologically active models, scaffold } \\
\text { free, freeform fabrication }\end{array}$ & $\begin{array}{l}\text { Fragile raw material, requires subsequent } \\
\text { spheroid fusion }\end{array}$ \\
\hline
\end{tabular}




\section{Biocompatible 3D Printing Materials}

In the field of biofabrication, there is clear distinction between direct printing of a cell-seeded material, termed a "bioink", and the printing of a cell-free scaffold from a "biomaterial ink", which can subsequently be seeded with cells or directly implanted [38,39]. Ink selection is driven by both the final function of the part and the printing technique to be used. Biomaterial inks are generally used to produce a rigid scaffold for the permanent or slow-degrading stabilization of a structure, while bioinks produce a softer scaffold that can be more rapidly replaced by the deposition of a new extracellular matrix (ECM) by the embedded cell population [32,39].

\subsection{Bioinks}

Many bioinks have been developed from hydrogels, which are very well established as suitable materials for 3D cell cultures [40-42]; they have very good biocompatibility and are highly tunable regarding their physical, mechanical and biological properties [42-44]. Hydrogels commonly show non-Newtonian, shear thinning behavior, which makes them suitable for extrusion bioprinting. Unmodified, however, they often have limitations regarding their print characteristics, which were described by Malda et al. [32]. Hydrogels, which make the best cell culture scaffolds, often have low viscosities prior to crosslinking, resulting in poor shape fidelity following extrusion-based printing, and limiting their capacity to form larger structures without features collapsing $[32,45,46]$. This has encouraged the development of both novel bioinks and new techniques for cell-seeded biofabrication in recent years [47]. Table 2 summarizes frequently used bioinks and their applications, while a number of specific recent examples are further detailed.

Table 2. Commonly used bioinks and their recent tissue engineering applications (PEG: polyethylene glycol; ECM: extracellular matrix; hMSCs: human mesenchymal stem cells; hMPCs: human muscle progenitor cells; HUVECs: human umbilical vein endothelial cells; PAVICs: porcine aortic valve interstitial cells; SCAP: stem cells from the apical papilla).

\begin{tabular}{ccc}
\hline Bioink & Cell Type/Tissue & Reference \\
\hline Alginate & Chondrocytes/Cartilage & {$[48,49]$} \\
Agarose & hMSCs & {$[50,51]$} \\
Collagen & Hepatocytes/Liver & {$[52]$} \\
Fibrin & hMPCs/Skeletal Muscle & {$[53]$} \\
Gelatin & HUVECs/Vascular structures & hMSCs/Bone \\
hMSCs/Cartilage & {$[36,54,55]$} \\
Gellan gum & Chondrocytes/Cartilage & \\
Hyaluronic & Osteoblasts/Bone & {$[47]$} \\
acid & Fibroblasts & {$[56]$} \\
PEG & hMSCs & {$[57,58]$} \\
Tissue-derived & Fibroblasts & {$[59-61]$} \\
ECM & SCAP/Dentin & \\
\hline
\end{tabular}

Biopolymer hydrogels that have been used for bioprinting include, but are not limited to, alginate, agarose, cellulose, collagen, fibrin, gelatin, gellan gum and hyaluronic acid. Alginate is a negatively charged polysaccharide derived from brown algae, and is one of the most commonly used hydrogels in both tissue engineering and bioprinting [62,63]. It crosslinks upon the addition of divalent cations, and can be functionalized by the addition of arginine-glycine-aspartate (RGD) moieties, which are responsible for cells binding to the extracellular matrix [64], facilitating interaction with the scaffold. Alginate is also frequently blended with other biopolymers to modify both its printing and biological properties. A recent study incorporated hydroxyapatite (HAp) into alginate to produce a bioink for production of a calcified cartilage matrix [49]. The addition of HAp into alginate caused a reduction in 
glucosaminoglycan (GAG) secretion of chondrocytes, an increase in production of Col II and an increase in calcified cartilage markers Col-X, ALP and Alizarin red staining [49]. The addition of sodium citrate allowed for a more-homogenous distribution of Hap, and also improved print characteristics by preventing clogging of the needle [49].

Gelatin is another natural biopolymer that has long been used in cell culture. Unmodified, it undergoes a thermoreversible sol-gel transition, but the speed of gelation is generally considered too slow to ensure shape fidelity. To overcome this, many groups have used gelatin methacrylate (GelMA) to enable UV crosslinking [65]. This has shown very good biocompatibility, degradability and is also a relatively inexpensive bioink $[66,67]$. A study by Byambaa et al. used GelMA functionalized with vascular endothelial growth factor (VEGF) moieties to bioprint spatially defined vascular structures (with HUVECs) within a bone-like (GelMA with silicate nanoparticles and hMSCs) construct [54].

GelMA has also been combined with methacrylated polyvinyl alcohol (PVA-MA) and a visible light photoinitatior to produce a bio-resin for digital light processing (DLP) lithography. This approach allows for freeform fabrication, without the constraints of producing lattices, and with resolution down to $25-50 \mu \mathrm{m}$. Human bone marrow derived MSCs was seeded into the bio-resin prior to printing and showed $>85 \%$ viability $24 \mathrm{~h}$ after UV polymerization. GelMA was shown to be an essential addition to PVA-MA for long-term (28 days) cell survival [36].

Components of ECM such as collagen, fibrin and gelatin have been used to recapitulate the ECM for cell culture scaffolds for decades, but many of the chemical and biological signals from whole ECM are missing. Tissue-derived decellularized ECM ( $\mathrm{dECM})$ has the potential to be a very functional bioink; however, the decellularization process often renders it very mechanically soft, so it requires blending with synthetic or natural materials to increase its integrity following printing [59]. In a recent study, decellularized dentin was prepared by first removing the pulp and enamel from molars, followed by grinding and decalcification. It was then mixed with sodium alginate and SCAPs to produce a printable bioink. Increasing the concentration of dentin matrix molecules caused a significant increase in the upregulation of dentin markers ALP and RUNX2 [60].

\subsection{Biomaterial Inks}

Biomaterial inks often require processing under conditions that are cytotoxic, such as extremes of temperature or the use of solvents; however, they can be loaded with therapeutic molecules that can withstand these processing conditions [6]. Thermoplastics, ceramics, composites and metals have all been additively manufactured for use in biomedical applications $[6,11,12]$.

\subsubsection{Synthetic Hydrogels}

Synthetic hydrogels are often not suitable for the direct seeding of cells, but have similar non-Newtonian properties to biopolymeric hydrogels, allowing them to be printed by extrusion. Pluronic is a commonly used synthetic ink that can be thermally crosslinked or functionalized with chemical groups for UV crosslinking. It has been used as support material for structures with overhangs, and also as a sacrificial ink to produce hollow structures $[48,55,68,69]$. Elastomers are also an attractive material for bioprinting, as their mechanical properties mimic the viscoelasticity of native tissues. Polydimethylsiloxane (PDMS) and silicon have been printed using embedded techniques (freeform reversible embedding (FRE) and printing into microgels, respectively) to produce hollow and bifurcating structures that mimic airways and large vessels [70,71]. These structures can then be perfused to model flow in large vessels [71].

\subsubsection{Thermoplastics and Resins}

Thermoplastics are common materials for 3D printing across many technical industries, and are also used by hobbyists. In bioprinting, the key advantage is that they can be processed and undergo multiple thermal cycles for the incorporation of factors, and to form filaments for extrusion, resins for photolithography or polymer melts for electrospinning. We have previously shown that 
off-the-shelf materials can be used in tissue engineering applications [11,12]. Thermoplastics such as polycaprolactone (PCL), polyvinyl alcohol (PVA) and polylactic acid (PLA) have been bioprinted for use as both supports for cell-seeded hydrogels that require mechanical reinforcement, and for direct implantation in vivo [55,72]. They are printed using extrusion from filaments or polymer melts so they can produce structures with high resolution and very good shape fidelity, giving excellent control over porosity, which can in turn influence the mechanical properties of the scaffold [73].

PORO-LAY are a group of PVA-polyurethane-elastomer blends that can be extrusion printed from filament before rinsing with water, to wash out the PVA component, leaving the nanoporous elastomer. We have shown the entrapment and subsequent controlled release of doxorubicin (a common anti-cancer drug) or zoledronate (anti-resorptive), over a period of seven days [6,7] in 3D-printed scaffolds. Using different variations of PORO-LAY with increasing levels of porosity, the total release of doxorubicin was also increased, inducing the largest decrease in metabolic activity in a prostate cancer cell line [6]. Delivery of cancer drugs to specific tissues is often achieved intravenously, but there is little currently done to prevent the venous spreading of excess drug to healthy tissues. A thermoplastic mesh-like filter was printed using continuous liquid interface production (CLIP) before being coated with a polystyrene-sulphonate absorber. The cylindrical filter device was printed and implanted in the iliac vein of a swine. Doxorubicin was then injected up-stream of the device, and the levels of doxorubicin in the blood were shown to be significantly lower after blood passed through the coated filter compared with the uncoated control [74]. This offers a solution by which a device can be implanted in large veins leading from diseased tissues to "mop-up" excess chemotherapeutics.

\subsubsection{Ceramics}

Ceramic materials are a mixture of inorganic salts, including calcium and phosphate, which are used for bone and dental applications due to their osteoconductivity. On their own, ceramics are very brittle, which makes them difficult to handle and implant; therefore, in biofabrication, ceramics are combined with a polymeric binder for extrusion bioprinting or 3D powder printing $[49,75]$. Commonly printed ceramics include tricalcium phosphate (TCP), hydroxyapatite (HAp), bi-phasic calcium phosphate (BCP), poly (methyl methacrylate) (PMMA) and bioglass. Tetracalcium phosphate (TTCP) is a promising candidate for bone replacement and has been shown to be highly resorbable at low $\mathrm{pH}$. A study by Mandal et al. showed the use of TTCP with a phytic acid binder. Following printing, and post-hardening with additional binder solution, TTCP was still the most abundant ceramic phase, but an amorphous calcium phosphate phase was also present, indicating a reaction between the ceramic powder and binder [76]. Ceramics have been used to functionalize PCL by mixing the powdered ceramic and polymer, producing a liquid melt and then extruding filaments to produce a multi-layered scaffold [77]. In this study, PCL blended with natural ceramics (decellularized bone matrix and Bio-Oss, a bovine derived bone mineral) outperformed synthetic ceramics (HAp and TCP) regarding osteoinductive capability [77].

\subsection{Metal Implants}

Metallic implants for orthopedic, dental and craniofacial applications have traditionally been manufactured from stainless steel, cobalt chromium molybdenum and titanium alloys by methods such as casting, forging and machining. Developments in AM technology have now enabled the production of implants designed from reconstructed 3D imaging data to produce patient-specific implants. A key area of recent research has been in adding functionality to these implants. A recent study showed how an antibiotic-eluting cement could be loaded into a central cavity within metallic implants that could not be manufactured by conventional methods [78]. Due to the high resolution achievable by selective laser melting (SLM) of metallic powders, intricate lattices can be produced [9,34]. This has been investigated to overcome issues surrounding stress shielding in hip implants. Finite element analysis (FEA) was initially used to determine the theoretical mechanical performance, as well as 
theoretical reductions in bone loss, of porous implants. They were then produced using SLM and FEA was confirmed by mechanical testing [9].

\section{Healthcare Applications}

\subsection{Tissue Engineering}

The field of tissue engineering plays a key role in fabrication of biocompatible implants to replace damaged or non-functional tissues. The principle behind tissue engineering revolves around combining biocompatible materials, live cells and growth factors to create implants that aid normal tissue growth throughout the engineered construct $[79,80]$. Additive manufacturing has fit well into tissue engineering, allowing for fabrication of 3D-printed models that mimic the microscopic network of connective tissue [79]. From porous implants that promote bone regeneration [81], to complex three-dimensional organoids composed of cells [82], the main advantage of 3D printing in tissue engineering is the ability it provides to make geometrically complex (potentially composite) structures by accurate placement of material or cells within a three-dimensional space.

\subsubsection{D Models and Organoids}

In vitro applications of tissue engineering have paved the way for the development of physiological models representing tissue-like human and animal microenvironments for more clinically applicable testing. Complex three-dimensional organizations of different cell types can allow for the creation of organoids and functional units of different organ systems for studying disease processes and treatment response. It has been shown that cells behave quite differently in terms of gene expression and signaling within a 3D environment, as opposed to conventional 2D cultures [83,84]. A study by Riedl et al. [83] comparing the response of 3D spheroids vs 2D cultures of human colon cancer cells lines observed contradictory levels of AKT/mTOR/S6K signaling activity upon treatment with the mTOR inhibitor rapamycin. They discovered that signaling was increased in 2D cultures, but decreased in 3D spheroids [83]. A subsequent xenografted mouse tumor model demonstrated that the 3D spheroid model was an accurate representation of the in vivo response to rapamycin treatment, showcasing the increased efficacy of 3D spheroids as accurate preclinical drug screening models compared to $2 \mathrm{D}$ cultures [83]. Although tumor spheroid models are a relatively inexpensive and a fast way of recreating in vivo-like environments [85], they are limited regarding their size and complexity [86]. Due to limitations concerning diffusion of nutrients, gases and wastes, spheroids can only grow to a certain size before hypoxia and lack of nutrients deteriorates the spheroid viability [86]. Additionally, fabrication methods for spheroid formation only allow for production of simple spheroids, without any design complexity, and they are also very fragile during handling [86].

As an AM technique, bioprinting allows the creation of complex 3D hydrogel models with great levels of control and reproducibility compared with conventional techniques such as molding and spheroid formation. While production of functional organs may still be decades away, bioprinting can already allow the creation of complex organ-on-a-chip models. With good anatomical, compositional and functional similarity to the host tissue, bioprinted 3D models can be used to conduct experiments in an in vivo-like physiological environment [87]. Organ development is a process that begins during the embryonic period, and so recreating the architectural environment and correct signaling patterns developed through this process is important for modeling both developmental and disease processes [88]. Current research efforts have been successful in reproducing functions of many different organs through differentiation and self-organization of stem cells into organoids [89,90]. Reliance on the self-organizing capabilities of stem cells, however, provides limited control regarding the shape, composition and final size of the organoid [91,92]. Through bioprinting, stem cells, cell lines and patient derived cells can be deposited with good spatial control to achieve any desired structural arrangement $[82,88,91-93]$. A study by Grix et al. [94] utilized stereolithography to produce $4 \mathrm{~mm}$ 3D liver lobule models. They comprised a hepatocyte-seeded GelMA (methacrylated gelatin) with 
degradable PEG (polyethylene glycol)-lined channels, mimicking the unique in vivo architecture of the liver. They demonstrated increased hepatocyte-specific gene expression within the 3D model as compared to 2D monolayer cultures [94]. Additionally, by embedding channels throughout the model, they created a vascular network that could be used to perfuse the model [94]. The high resolution that stereolithography technology enables allowed printing of microscopic details within this model [94]. Another study by Bulanova et al. [95] used material extrusion bioprinting technology and a collagen-based bioink to create a vascularized thyroid gland model. Through bioprinting, they were able to create a model consisting of embryonic stem-cell-derived thyroid spheroids and epithelial spheroids, in close proximity to each other, that allowed for invasion and vascularization of the thyroid spheroids by the epithelial cells [95]. They also confirmed the functionality and neovascularization of the organoid by achieving thyroid homeostasis after implanting the bioprinted organoid in hypothyroid mice [95].

Bioprinting has emerged over the past few years as a capable method for creating highly complex organoids and lab models. To date, many labs have utilized this technique for creating biologically functioning models made up of a wide variety of tissues such as liver $[87,94,96]$, mammary epithelium [97], myocardium [98], skeletal muscle [53], kidney [61], skin [14,93], neurons [99] and malignant tumors [100]. These models are becoming useful drug screening tools within both research labs and the pharmaceutical industry $[98,101-103]$. There are, however, a few limitations associated with bioprinting. The properties of currently used bioinks result in a trade-off between creating a viable growth environment for cells, while providing structural support to the printed model. More elastic biomaterials can allow for creation of complex models that can hold their shape but at the same time limit cellular interactions and movement [104]. More viscous biomaterials create a fluid environment for cells, while having less capability to create large models without collapsing under their own weight [105]. As the field of bioprinting advances, so does the need for discovering new biomaterials that provide structural support without hindering cell viability and extracellular matrix deposition.

\subsubsection{Implants}

The field of surgical implants and prostheses is continuously developing to allow for more cohesive integration of these foreign objects within their surrounding tissue, as well as to increase their functionality. Design of implants and prostheses requires a multidisciplinary approach that combines principles of materials science, engineering, biomechanics, molecular biology, pharmaceuticals and long-term clinical monitoring. AM can help bridge the gap between biology and engineering by creating complex biocompatible and bioactive constructs that take advantage of unique material properties, such as osteoconductivity and osteoinductivity, to promote tissue regeneration and integration of the implant with the surrounding tissue. Current radiological imaging technology, such as computed tomography (CT), can allow for creation of very accurate CAD models of a defect that can serve as models for 3D printing to ensure a perfect fit into the desired tissue [106].

\section{Tissue Regeneration}

AM has been established as an effective tool for production of implants that promote bone regeneration in vitro and in vivo [10,107-109]. Management of critical-size bone defects is highly challenging, often resulting in significant morbidity [110]. Simply filling a large bone defect with bone graft may not guarantee bone integration due to an absent coherent blood supply to the graft $[110,111]$. Current surgical management options include vascularizing a bone graft, which is difficult and highly technical, or performing a Masquelet procedure, which is effective at restoring blood supply, but requires multiple operations and therefore increases morbidity [110]. AM offers potential implant solutions that could promote both vascularization and bone regeneration $[109,112]$. Porosity is an important property for promotion of bone ingrowth. 3D printing provides the technical capability to create high-resolution, porous scaffolds from a wide variety of materials including metals, ceramics and biodegradable polymers [113]. Other regenerative capabilities of AM-fabricated scaffolds aside from 
bone have also been studied. A study by Lee et al. [114] demonstrated the printing and implantation of an acellular hydroxyapatite/PCL scaffold doped with transforming growth factor $\beta 3$ (TGF 33 ) into rabbits. It resulted in full regrowth of the articular surface of the proximal humeral joint, and the regenerated cartilage had comparable histological, compressive and shear properties to that of native rabbit articular cartilage [114]. Similar findings with hyaline cartilage were observed by Chang et al. [115], where an FDM-printed PCL trachea, coated with MSCs and fibrin, demonstrated production of neocartilage, as well as integration with native tracheal tissue. Tissue regeneration using FDM-printed scaffolds have also been reported with hydroxyapatite-PCL scaffolds in the periodontium [116].

Implant-Tissue Interface

The initial physical interaction of implants with surrounding tissue occurs on the implant surface. This adds another dimension to factors that affect implant failure over time, such as stress shielding due to differences in mechanical properties (compared with the surrounding tissue) and implant wear-induced cell death from movement across the implant-tissue interface [117]. Therefore, it is imperative to consider implant surface characteristics that aid in better integration and fixation to the surrounding tissue. Surface roughness of metallic bone implants is an important factor that inversely correlates with biological fixation to the surrounding bone. A study by MacBarb et al. [118] demonstrated that 3D-printed titanium spinal implants using electron beam melting (EBM; a type of powder bed fusion technique) were superior for inducing osteoblast proliferation and calcium production on implant surface in vitro as opposed to the current standard of implant surface processing (titanium plasma spraying). They achieved this through incorporating a cancellous bone-like trabecular network on the implant surface 3D model, and subsequently achieving high-resolution fabrication using AM [118]. Nanofabrication techniques have also been used to produce porous coatings for 3D-printed implants. A study by Garcia et al. [119] showcased how by coating titanium implants with fibronectin nanoclusters resulted in a significant increase in integrin binding, resulting in improved implant fixation in rats. Another study by Tran et al. [120] used selenium nanoclusters as a coating on titanium implants in an in vitro model. Their results showed that selenium nanoclusters had enhanced antitumor activity, while also promoting healthy bone formation on the bone surface compared to untreated implants [120].

\section{Dentistry}

Patient anatomical variability in dentistry has driven the field to adopt a customized approach for the management of each patient. Recent advancements in scanning and imaging technologies have resulted in highly accurate 3D reconstructions of the oral cavity to serve as a template for designing custom oral prostheses and implants [121,122]. In the field of prosthodontics (dentures), AM is clinically established as a feasible and accurate approach for fabricating prostheses with comparable durability to conventional manufacturing techniques and materials [123-125]. Stereolithography is a commonly used technique in this field, with established commercial resin products available [126]. In orthodontics (retainers), CAD models of a patient's oral cavity and teeth are used to simulate the final teeth-alignment goal, and to print a corresponding mold for fabricating custom silicon prostheses [127]. In oral and maxillofacial surgery, a major role of AM is in 3D printing custom biocompatible and osteoinductive implants to accurately fill bone defects and promote regeneration of the bone [128], which will be further discussed below.

\section{Orthopedics}

Implants play a key role in the management of patients with orthopedic injuries in order to restore alignment, structural integrity and motion. Most implants are available in standard sizes designed to fit most patients. However, patients on the extreme ends of anatomical variability or deformity might require specialized implants to ensure a proper fit [129]. Much like dentistry, CAD models of 
patient anatomy generated through radiological imaging allow for design and fabrication of custom-fit implants using AM. Orthopedic implants also need to integrate (or even regenerate) with the patient's own bone, which creates tissue support and prevents implant failure. There are a few factors relating to implant structure and composition that drive its ability to promote bone regeneration. Porosity is an important property that makes an implant penetrable to tissue and vessel ingrowth [130]. High-resolution AM techniques are well suited for creating highly porous implants that allow for an interwoven mesh of bone to secure the implant to the surrounding bony tissue [9]. Additionally, 3D printing of bioabsorbable and osteoinductive materials, such as calcium phosphate cement, has been shown to be very effective at inducing bone growth [131,132]. Lastly, the ability of the implant to concentrate the effect of drugs and growth factors (such as bone morphogenetic protein (BMP) or VEGF) through local and sustained release at the site of implantation can allow for decreased systemic exposure to these compounds. Furthermore, lower quantities of therapeutics would be required, leading to increased cost-effectiveness [6,133]. It is also important to point out the feasibility for using 3D printing for orthosis generation, such as patient-specific casts for fractures [134].

\subsection{Drug Delivery}

The role of AM in the pharmaceutical industry is very diverse [135]. Developing new techniques for controlled release of drugs from different routes of administration continues to be an area of interest for research. Common routes of drug administration are ingestible tablets and implantable devices that offer a predetermined rate of drug release. Here we describe some novel ways where AM is being utilized for improving drug delivery.

\subsubsection{Tablets}

Solid-form tablets are manufactured using compression of a powder mixture containing the active pharmaceutical ingredient (API) into molds [136]. This industrial process is efficient for producing large quantities of simple tablets; however, it is not well suited for the creation of tablets with complex structures and variable dosing. AM provides an opportunity in this field by allowing the fabrication of specialized tablets that perform complex and unique functions customizable for different patients. Fused deposition modeling (FDM) is a commonly used 3D printing technique due to its low cost and speed for creating ready-to-use tablets $[137,138]$. Other printing techniques outlined in this review are also utilized, however, mainly for research purposes [139,140]. A study by Sadia et al. [137] showcased how 3D printing a tablet with holes $>0.6 \mathrm{~mm}$ throughout allowed for release mechanics that qualified for an "immediate release" designation as outlined by United States Pharmacopeia (USP) as compared with same-dimension solid tablets that did not meet the designation. Their tablets were printed from hydrochlorothiazide-impregnated thermoplastics and they attributed the improved release characteristics to an increased surface-to-volume ratio achieved using a 3D-printed design [137]. Another study by Khaled et al. [141] utilized FDM and a hydroalcoholic gel-based paste to print a three-compartment tablet capable of releasing three different therapeutics (captopril, nifedipine, glipizide). Interestingly, through modification of the paste, they demonstrated that a single tablet was able to release Captopril with zero-order kinetics while releasing the other two drugs with first-order or other kinetics [141]. It is challenging for conventional tablet manufacturing techniques to offer a wide range of tablet dosing; hence, only certain established doses of drugs exist. However, given the vast variability in the physiology of every patient, a standard dose of a drug can have a variable side-effect profile between different patients [142,143]. Therefore, AM provides an economic solution for producing customizable tablets with functions tailored to each patient. Recent studies have also shown the potential of AM for on-demand tablet printing for use in emergencies and for printing tablets containing perishable APIs $[5,144]$. 


\subsubsection{Transdermal Delivery}

Transdermal drug delivery takes advantage of skin circulation as a distribution network for the sustained release of a multitude of drugs [145]. This is a non-invasive solution compared to ingestion, injection or insertion drug delivery methods [146]. Current methods of transdermal drug delivery are patches and microneedle arrays. Patches provide a continuous supply of a drug to the upper layers of the epidermis, serving as a reservoir for drugs to passively release into deeper-layer vessels [146]. Microneedle arrays are composed of a patch with microscopic needle-like projections that penetrate the upper layer of the skin. This allows for better penetration of a drug without disrupting skin integrity, reducing the risk of infection or other complications associated with more invasive tools such as hypodermic needle [146]. AM can offer an advantage in patch manufacturing by allowing the fabrication of patches containing a mixture of drugs, or of patches with complex structures, allowing for different rates of drug release from the same patch [146]. High-resolution AM techniques, such as SLA, have been employed to fabricate microneedles with a high degree of precision and speed using a diverse variety of materials [147]. Inkjet printing is another AM method used to coat these microneedles with a uniform level of drug in a controlled and reproducible manner [148].

\subsubsection{Drug-Releasing Implants}

Implants play a wide variety of functions in medicine to restore anatomical integrity, conduct procedures and aid normal physiological functions. Long-term implants such as plates, joints, screws, stents or cement require the use of materials that do not interfere with normal functioning of the surrounding tissue. Temporary implants, such as urinary or vascular access catheters, require antibacterial coatings to prevent catheter-associated infections [149]. Aside from the great level of control AM provides in fabricating complex implants, it also allows the incorporation of therapeutics within an implant's structure [150]. The use of composite biocompatible materials within implants can allow for controlling the rate of release of drugs from these implants [150]. Studies have shown that 3D-printed antibiotic-infused PLA constructs are superior in prevention of bacterial biofilm formation compared to constructs that are only coated with antibiotics [151]. In vitro studies on extrusion 3D-printed scaffolds in our lab have also shown equal efficacy in drug release as compared to direct treatment with drugs, highlighting the potential for the use of 3D-printed scaffolds for sustained local drug delivery within tissue $[6,7]$.

\subsection{Surgical Tools}

Advancements in radiological imaging have allowed the creation of CAD reconstructions of patient anatomy, providing potential for designing and fabricating patient-specific, customized surgical instruments [152]. Most surgical tools are designed to work with most patients. However, unique anatomical features or complex procedures could benefit from customized tools that allow for a more-controlled and simplified operative experience, in turn decreasing risk of complications [153]. $\mathrm{AM}$ is a very effective tool in rapidly converting CAD designs into usable tools that could serve the ongoing needs of high-output institutions such as hospital operating rooms. AM-fabricated tools have been effectively sterilized and used for drill and cutting guides [154], retractors [155] and jigs. One study showcased how a 3D-printed PLA-based retractor was able to perform as well as its stainless counterpart, while costing 10 times less [155]. One can imagine the large savings for institutions if this technology were implemented broadly. Interestingly, some studies have suggested the feasibility and effectiveness of 3D printing surgical tools for emergencies on long-term space missions, such as a trip to Mars [156,157]. More realistically, the cost-effectiveness of using 3D-printed surgical tools or casts in low-income countries and institutions has high feasibility [155]. 


\subsection{Operative Planning}

Perhaps one of the most established and publicized applications of AM in surgery is its use in operative planning. Through imaging modalities such as CT, accurate CAD replicas of patient anatomy can be generated using high-resolution AM techniques such as SLA [158]. These models provide surgeons superior visual and tactile appreciation of complex injuries and deformities that would otherwise be difficult to fully assess with 2D radiological imaging [8]. These models can be used intraoperatively as well as after sterilization. Ultimately, these accurate 3D models have allowed surgeons to better plan complicated operations, such as the surgical approach or requirement of specific tools [8]. Some of the common applications for 3D models for operative planning are complex pelvic trauma [159], pediatric deformities [8] and osteotomies [160].

\section{Open-Source Tools for 3D Bioprinting}

As 3D printing developed into a platform for hobbyists to design and produce parts, there was a rapid increase in the availability of open source software and 3D designs for printing. Many of these freely available tools are translatable alongside new ones that are directly applicable to the biomedical field. A few examples are detailed here.

- $3 \mathrm{D}$ printers

○ RepRap - an online resource for all things 3D printing, including how to build custom 3D printers [161]. As many bioprinters have unique applications and require specific functions, many groups have modified low-cost FDM printers for affordable bioprinting set-ups [162,163].

$\bigcirc \quad$ Feinberg et al.- - this group recently released a complete set of instructions along with .stl files to print a "large volume syringe pump extruder for desktop 3D printers" [164]. This enables the user to convert a low-cost FDM filament printer into a bioprinter for the extrusion of gel or paste-like bioinks.

- 3D CAD models

- NIH 3D Print Exchange-an online free database of scientifically accurate and medically applicable models. Ranging from prosthetics to protein structures, the database has almost 7000 3D models that are free to download.

○ Thingiverse (MakerBot) - a large online database of general 3D models. It includes a selection of anatomical models and models for a range of medical tools and devices uploaded by the printing community.

- $\quad$ Slicing software

Slic3r, Cura (Ultimaker), Repetier-Host, etc.- there are many different open-source slicing packages available that all have similar functions and can be adapted for use with most 3D printers.

- PetriPrinter-a G-code generator developed with bioprinting for cell culture in mind, this software enables the user to design printing set-ups for multiple culture plates or petri dishes [165].

- $\quad$ Resources

Bioverse (Cellink)—an online community of researchers involved in bioprinting where CAD models, protocols and other resources are shared for free.

Embodi3D-an online biomedical 3D-printing community providing printable anatomic body parts (.stl files) and tools for converting medical dicom image stacks into printable files as a freeware service. 


\section{Conclusions}

This review focused on the current biomedical applications of AM and the advantages it provides over conventional fabrication methods. As AM technology advances, not only can we expect the cost of hardware to decrease, but we can also expect new and unique materials to develop that can improve its biomedical and tissue engineering applications. Thermoplastics for low-cost 3D printing have almost become mainstream, with their use evident in many hospitals and research institutes. New and translational materials are being generated at a high rate, which may allow for clinical use in tissue-repair applications in the very near future. Bioprinting has emerged as a very effective tool for creating tissue-like 3D models representing physiological systems for drug screening and disease modelling. Bioprinting has been successful in creating small functional units of organs called organoids. However, the greatest opportunity for bioprinting lies in its potential for printing a fully functioning organ that can be transplanted into a patient. This would eliminate the need for waitlists or rigorous testing for histocompatibility, as the patient's own cells can be used in the bioprinting process. Bioprinting technology must overcome issues, such as microvascularization and bioink longevity, before attempting to print a full organ. However, with the current rate of development it is very exciting to see what the near future holds.

Author Contributions: Writing—original draft preparation, P.A. and M.E.C.; writing—review and editing, P.A., M.E.C., M.H.W. and D.H.R.; visualization, P.A., M.E.C. and D.H.R.; supervision, M.H.W. and D.H.R.; project administration, M.H.W. and D.H.R.; funding acquisition, M.H.W. and D.H.R.

Funding: This research received no external funding. The APC was funded by start-up funds to DHR from the Research Institute of McGill University Health Centre.

Acknowledgments: M.E.C. thanks the réseau de recherche en santé buccodentaire et osseuse (RSBO) for funding a fellowship and D.H.R. thanks RI-MUHC for start-up funds.

Conflicts of Interest: The authors declare no conflict of interest. The funders had no role in the design of the study; in the collection, analyses, or interpretation of data; in the writing of the manuscript, or in the decision to publish the results.

\section{References}

1. Zadpoor, A.A. Design for Additive Bio-Manufacturing: From Patient-Specific Medical Devices to Rationally Designed Meta-Biomaterials. Int. J. Mol. Sci. 2017, 18, 1607. [CrossRef] [PubMed]

2. Hu, Q.; Sun, X.Z.; Parmenter, C.D.J.; Fay, M.W.; Smith, E.F.; Rance, G.A.; He, Y.; Zhang, F.; Liu, Y.; Irvine, D.; et al. Additive manufacture of complex 3D Au-containing nanocomposites by simultaneous two-photon polymerisation and photoreduction. Sci. Rep. 2017, 7, 17150. [CrossRef] [PubMed]

3. McHugh, K.J.; Nguyen, T.D.; Linehan, A.R.; Yang, D.; Behrens, A.M.; Rose, S.; Tochka, Z.L.; Tzeng, S.Y.; Norman, J.J.; Anselmo, A.C.; et al. Fabrication of fillable microparticles and other complex 3D microstructures. Science 2017, 357, 1138-1142. [CrossRef] [PubMed]

4. Hull, C.W. Apparatus for Production of Three-Dimensional Objects by Stereolithography. U.S. Patent 4,575,330, 11 March 1986.

5. Norman, J.; Madurawe, R.D.; Moore, C.M.; Khan, M.A.; Khairuzzaman, A. A new chapter in pharmaceutical manufacturing: 3D-printed drug products. Adv. Drug Deliv. Rev. 2017, 108, 39-50. [CrossRef] [PubMed]

6. Ahangar, P.; Akoury, E.; Ramirez Garcia Luna, A.; Nour, A.; Weber, M.; Rosenzweig, D. Nanoporous 3D-Printed Scaffolds for Local Doxorubicin Delivery in Bone Metastases Secondary to Prostate Cancer. Materials 2018, 11, 1485. [CrossRef]

7. Akoury, E.; Weber, M.H.; Rosenzweig, D.H. 3D-Printed nanoporous scaffolds impregnated with zoledronate for the treatment of spinal bone metastases. MRS Adv. 2019, 156, 1-7. [CrossRef]

8. Coelho, G.; Chaves, T.M.F.; Goes, A.F.; Del Massa, E.C.; Moraes, O.; Yoshida, M. Multimaterial 3D printing preoperative planning for frontoethmoidal meningoencephalocele surgery. Child's Nerv. Syst. 2018, 34, 749-756. [CrossRef]

9. Arabnejad, S.; Johnston, B.; Tanzer, M.; Pasini, D. Fully porous 3D printed titanium femoral stem to reduce stress-shielding following total hip arthroplasty. J. Orthop. Res. 2017, 35, 1774-1783. [CrossRef] 
10. Yang, C.; Wang, X.; Ma, B.; Zhu, H.; Huan, Z.; Ma, N.; Wu, C.; Chang, J. 3D-Printed Bioactive Ca3SiO5 Bone Cement Scaffolds with Nano Surface Structure for Bone Regeneration. ACS Appl. Mater. Interfaces 2017, 9, 5757-5767. [CrossRef]

11. Rosenzweig, D.H.; Carelli, E.; Steffen, T.; Jarzem, P.; Haglund, L. 3D-Printed ABS and PLA Scaffolds for Cartilage and Nucleus Pulposus Tissue Regeneration. Int. J. Mol. Sci. 2015, 16, 15118-15135. [CrossRef]

12. Fairag, R.; Rosenzweig, D.; Ramirez Garcialuna, J.L.; Weber, M.H.; Haglund, L. 3D-Printed Polylactic Acid (PLA) Scaffolds Promote Bone-like Matrix Deposition In-vitro. ACS Appl. Mater. Interfaces 2019. [CrossRef]

13. Vikram Singh, A.; Hasan Dad Ansari, M.; Wang, S.; Laux, P.; Luch, A.; Kumar, A.; Patil, R.; Nussberger, S. The Adoption of Three-Dimensional Additive Manufacturing from Biomedical Material Design to 3D Organ Printing. Appl. Sci. 2019, 9, 811. [CrossRef]

14. Cubo, N.; Garcia, M.; Del Canizo, J.F.; Velasco, D.; Jorcano, J.L. 3D bioprinting of functional human skin: Production and in vivo analysis. Biofabrication 2016, 9, 015006. [CrossRef]

15. Gao, G.; Hubbell, K.; Schilling, A.F.; Dai, G.; Cui, X. Bioprinting Cartilage Tissue from Mesenchymal Stem Cells and PEG Hydrogel. Methods Mol. Biol. 2017, 1612, 391-398.

16. Zhou, X.; Zhu, W.; Nowicki, M.; Miao, S.; Cui, H.; Holmes, B.; Glazer, R.I.; Zhang, L.G. 3D Bioprinting a Cell-Laden Bone Matrix for Breast Cancer Metastasis Study. ACS Appl. Mater. Interfaces 2016, 8, 30017-30026. [CrossRef]

17. ISO. ISO/ASTM-52900:2015 (ASTM F2792) Additive Manufacturing-General Principles-Terminology; ISO: Geneva, Switzerland, 2015.

18. Sachs, E.; Cima, M.; Cornie, J. Three-Dimensional Printing: Rapid Tooling and Prototypes Directly from a CAD Model. CIRP Ann. 1990, 39, 201-204. [CrossRef]

19. Deckard, C.R. Method and Apparatus for Producing Parts by Selective Sintering. U.S. Patent 4,863,538, 5 September 1989.

20. Keicher, D.; Romero, J.A.; Atwood, C.L.; Griffith, M.L.; Jeantette, F.P.; Harwell, L.D.; Greene, D.L.; Smugeresky, J.E. Laser Engineered Net Shaping (LENS\{trademark\}) for Additive Component Processing; Sandia National Labs.: Albuquerque, NM, USA, 1996.

21. Crump, S.S. Apparatus and Method for Creating Three-Dimensional Objects. U.S. Patent 5,121,329, 9 June 1992.

22. Masters, W.E. Computer Automated Manufacturing Process and System. U.S. Patent 4,665,492, 12 May 1987.

23. Wu, P.K.; Ringeisen, R.B.; Callahan, J.; Brooks, M.; Bubb, D.M.; Wu, H.D.; Piqué, A.; Spargo, B.; McGill, R.A.; Chrisey, D.B. The deposition, structure, pattern deposition, and activity of biomaterial thin-films by matrix-assisted pulsed-laser evaporation (MAPLE) and MAPLE direct write. Thin Solid Films 2001, 398, 607-614. [CrossRef]

24. Ghidini, T. Regenerative medicine and 3D bioprinting for human space exploration and planet colonisation. J. Thorac. Dis. 2018, 10 (Suppl. 20), S2363-S2375. [CrossRef]

25. Cui, X.; Boland, T. Human microvasculature fabrication using thermal inkjet printing technology. Biomaterials 2009, 30, 6221-6227. [CrossRef]

26. Stringer, J.; Derby, B. Formation and stability of lines produced by inkjet printing. Langmuir 2010, 26, 10365-10372. [CrossRef]

27. Cui, X.; Dean, D.; Ruggeri, Z.M.; Boland, T. Cell damage evaluation of thermal inkjet printed Chinese hamster ovary cells. Biotechnol. Bioeng. 2010, 106, 963-969. [CrossRef] [PubMed]

28. Michael Feygin, S.S.P. Laminated Object Manufacturing Apparatus and Method. U.S. Patent 5,876,550, 2 May 1999.

29. Biswas, A.; Bayer, I.S.; Biris, A.S.; Wang, T.; Dervishi, E.; Faupel, F. Advances in top-down and bottom-up surface nanofabrication: Techniques, applications \& future prospects. Adv. Colloid Interface Sci. 2012, 170, 2-27. [PubMed]

30. Ruiz-Hitzky, E.; Aranda, P.; Darder, M.; Ogawa, M. Hybrid and biohybrid silicate based materials: Molecular vs. block-assembling bottom-up processes. Chem. Soc. Rev. 2011, 40, 801-828. [CrossRef]

31. Hong, D.; Chou, D.T.; Velikokhatnyi, O.I.; Roy, A.; Lee, B.; Swink, I.; Issaev, I.; Kuhn, H.A.; Kumta, P.N. Binder-jetting 3D printing and alloy development of new biodegradable Fe-Mn-Ca/Mg alloys. Acta Biomater. 2016, 45, 375-386. [CrossRef] [PubMed]

32. Malda, J.; Visser, J.; Melchels, F.P.; Jüngst, T.; Hennink, W.E.; Dhert, W.J.; Groll, J.; Hutmacher, D.W. 25th anniversary article: Engineering hydrogels for biofabrication. Adv. Mater. 2013, 25, 5011-5028. [CrossRef] 
33. Boland, T.; Tao, X.; Damon, B.J.; Manley, B.; Kesari, P.; Jalota, S.; Bhaduri, S. Drop-on-demand printing of cells and materials for designer tissue constructs. Mater. Sci. Eng. C 2006, 27, 372-376. [CrossRef]

34. Burton, H.E.; Eisenstein, N.M.; Lawless, B.M.; Jamshidi, P.; Segarra, M.A.; Addison, O.; Shepherd, D.E.T.; Attallah, M.M.; Grover, L.M.; Cox, S.C. The design of additively manufactured lattices to increase the functionality of medical implants. Mater. Sci. Eng. C Mater. Biol. Appl. 2019, 94, 901-908. [CrossRef]

35. Rahman, Z.; Barakh Ali, S.F.; Ozkan, T.; Charoo, N.A.; Reddy, I.K.; Khan, M.A. Additive Manufacturing with 3D Printing: Progress from Bench to Bedside. AAPS J. 2018, 20, 101. [CrossRef]

36. Castilho, M.D.; Malda, J.; Levato, R.; Alcala-Orozco, C.R.; Melchels, F.P.W.; Gawlitta, D.; Hooper, G.J.; Woodfield, T.B.F.; Costa, P.F.; Lim, K.S.; et al. Bio-resin for high resolution lithography-based biofabrication of complex cell-laden constructs. Biofabrication 2018, 10, 034101.

37. Mironov, V.; Visconti, R.P.; Kasyanov, V.; Forgacs, G.; Drake, C.J.; Markwald, R.R. Organ printing: Tissue spheroids as building blocks. Biomaterials 2009, 30, 2164-2174. [CrossRef] [PubMed]

38. Groll, J.; Boland, T.; Blunk, T.; Burdick, J.A.; Cho, D.W.; Dalton, P.D.; Derby, B.; Forgacs, G.; Li, Q.; Mironov, V.A.; et al. Biofabrication: Reappraising the definition of an evolving field. Biofabrication 2016, 8 , 013001. [CrossRef] [PubMed]

39. Groll, J.; Burdick, J.A.; Cho, D.-W.; Derby, B.; Gelinsky, M.; Heilshorn, S.C.; Jüngst, T.; Malda, J.; Mironov, V.A.; Nakayama, K.; et al. A definition of bioinks and their distinction from biomaterial inks. Biofabrication 2018, 11, 013001. [CrossRef] [PubMed]

40. Chaudhuri, O.; Gu, L.; Klumpers, D.; Darnell, M.; Bencherif, S.A.; Weaver, J.C.; Huebsch, N.; Lee, H.-P.P.; Lippens, E.; Duda, G.N.; et al. Hydrogels with tunable stress relaxation regulate stem cell fate and activity. Nat. Mater. 2015, 15, 326-333. [CrossRef] [PubMed]

41. Hunt, N.C.; Grover, L.M. Cell encapsulation using biopolymer gels for regenerative medicine. Biotechnol. Lett. 2010, 32, 733-742. [CrossRef] [PubMed]

42. Drury, J.L.; Mooney, D.J. Hydrogels for tissue engineering: Scaffold design variables and applications. Biomaterials 2003, 24, 4337-4351. [CrossRef]

43. Lee, J.-H.; Kim, H.-W. Emerging properties of hydrogels in tissue engineering. J. Tissue Eng. 2018, 9, 204173141876828. [CrossRef]

44. Green, J.J.; Elisseeff, J.H. Mimicking biological functionality with polymers for biomedical applications. Nature 2016, 540, 386-394. [CrossRef]

45. Ribeiro, A.; Blokzijl, M.M.; Levato, R.; Visser, C.W.; Castilho, M.; Hennink, W.E.; Vermonden, T.; Malda, J. Assessing bioink shape fidelity to aid material development in 3D bioprinting. Biofabrication 2018, 10, 014102. [CrossRef]

46. Jungst, T.; Smolan, W.; Schacht, K.; Scheibel, T.; Groll, J. Strategies and Molecular Design Criteria for 3D Printable Hydrogels. Chem. Rev. 2016, 116, 1496-1539. [CrossRef]

47. Moxon, S.R.; Cooke, M.E.; Cox, S.C.; Snow, M.; Jeys, L.; Jones, S.W.; Smith, A.M.; Grover, L.M. Suspended Manufacture of Biological Structures. Adv. Mater. 2017, 29, 1605594. [CrossRef]

48. Kesti, M.; Eberhardt, C.; Pagliccia, G.; Kenkel, D.; Grande, D.; Boss, A.; Zenobi-Wong, M. Bioprinting Complex Cartilaginous Structures with Clinically Compliant Biomaterials. Adv. Funct. Mater. 2015, 25, 7406-7417. [CrossRef]

49. You, F.; Chen, X.; Cooper, D.M.L.; Chang, T.; Eames, B.F. Homogeneous hydroxyapatite/alginate composite hydrogel promotes calcified cartilage matrix deposition with potential for three-dimensional bioprinting. Biofabrication 2019, 11, 015015. [CrossRef]

50. Duarte Campos, D.F.; Blaeser, A.; Weber, M.; Jäkel, J.; Neuss, S.; Jahnen-Dechent, W.; Fischer, H. Three-dimensional printing of stem cell-laden hydrogels submerged in a hydrophobic high-density fluid. Biofabrication 2012, 5, 015003. [CrossRef] [PubMed]

51. López-Marcial, G.R.; Zeng, A.Y.; Osuna, C.; Dennis, J.; García, J.M.; O’Connell, G.D. Agarose-Based Hydrogels as Suitable Bioprinting Materials for Tissue Engineering. ACS Biomater. Sci. Eng. 2018, 4, 3610-3616. [CrossRef]

52. Mazzocchi, A.; Devarasetty, M.; Huntwork, R.; Soker, S.; Skardal, A. Optimization of collagen type I-hyaluronan hybrid bioink for 3D bioprinted liver microenvironments. Biofabrication 2018, 11, 015003. [CrossRef] [PubMed]

53. Kim, J.H.; Seol, Y.-J.; Ko, I.K.; Kang, H.-W.; Lee, Y.K.; Yoo, J.J.; Atala, A.; Lee, S.J. 3D Bioprinted Human Skeletal Muscle Constructs for Muscle Function Restoration. Sci. Rep. 2018, 8, 1-5. [CrossRef] [PubMed] 
54. Byambaa, B.; Annabi, N.; Yue, K.; Trujillo-de Santiago, G.; Alvarez, M.M.; Jia, W.; Kazemzadeh-Narbat, M.; Shin, S.R.; Tamayol, A.; Khademhosseini, A. Bioprinted Osteogenic and Vasculogenic Patterns for Engineering 3D Bone Tissue. Adv. Healthc. Mater. 2017, 6, 1-15. [CrossRef] [PubMed]

55. de Ruijter, M.; Ribeiro, A.; Dokter, I.; Castilho, M.; Malda, J. Simultaneous Micropatterning of Fibrous Meshes and Bioinks for the Fabrication of Living Tissue Constructs. Adv. Healthc. Mater. 2019, 8, e1800418. [CrossRef]

56. Ouyang, L.; Highley, C.B.; Rodell, C.B.; Sun, W.; Burdick, J.A. 3D Printing of Shear-Thinning Hyaluronic Acid Hydrogels with Secondary Cross-Linking. ACS Biomater. Sci. Eng. 2016, 2, 1743-1751. [CrossRef]

57. Hockaday, L.A.; Kang, K.H.; Colangelo, N.W.; Cheung, P.Y.C.; Duan, B.; Malone, E.; Wu, J.; Girardi, L.N.; Bonassar, L.J.; Lipson, H.; et al. Rapid 3D printing of anatomically accurate and mechanically heterogeneous aortic valve hydrogel scaffolds. Biofabrication 2012, 4, 035005. [CrossRef]

58. Zheng, Z.; Wu, J.; Liu, M.; Wang, H.; Li, C.; Rodriguez, M.J.; Li, G.; Wang, X.; Kaplan, D.L. 3D Bioprinting of Self-Standing Silk-Based Bioink. Adv. Healthc. Mater. 2018, 7, 1701026. [CrossRef] [PubMed]

59. Choudhury, D.; Tun, H.W.; Wang, T.; Naing, M.W. Organ-Derived Decellularized Extracellular Matrix: A Game Changer for Bioink Manufacturing? Trends Biotechnol. 2018, 36, 787-805. [CrossRef] [PubMed]

60. Athirasala, A.; Tahayeri, A.; Thrivikraman, G.; França, C.M.; Monteiro, N.; Tran, V.; Ferracane, J.; Bertassoni, L.E. A dentin-derived hydrogel bioink for 3D bioprinting of cell laden scaffolds for regenerative dentistry. Biofabrication 2018, 10, 024101. [CrossRef] [PubMed]

61. Ali, M.; Yoo, J.J.; Zahran, F.; Atala, A.; Lee, S.J. A Photo-Crosslinkable Kidney ECM-Derived Bioink Accelerates Renal Tissue Formation. Adv. Healthc. Mater. 2019, 8, 1800992. [CrossRef]

62. Lee, K.Y.; Mooney, D.J. Alginate: Properties and biomedical applications. Prog. Polym. Sci. 2012, 37, $106-126$. [CrossRef] [PubMed]

63. Cooke, M.E.; Pearson, M.J.; Moakes, R.J.A.; Weston, C.J.; Davis, E.T.; Jones, S.W.; Grover, L.M. Geometric confinement is required for recovery and maintenance of chondrocyte phenotype in alginate. APL Bioeng. 2017, 1, 016104. [CrossRef]

64. Rowley, J.A.; Mooney, D.J. Alginate type and RGD density control myoblast phenotype. J. Biomed. Mater. Res. 2002, 60, 217-223. [CrossRef] [PubMed]

65. Klotz, B.J.; Gawlitta, D.; Rosenberg, A.J.W.P.; Malda, J.; Melchels, F.P.W. Gelatin-Methacryloyl Hydrogels: Towards Biofabrication-Based Tissue Repair. Trends Biotechnol. 2016, 34, 394-407. [CrossRef]

66. Pepelanova, I.; Kruppa, K.; Scheper, T.; Lavrentieva, A. Gelatin-Methacryloyl (GelMA) Hydrogels with Defined Degree of Functionalization as a Versatile Toolkit for 3D Cell Culture and Extrusion Bioprinting. Bioengineering 2018, 5, 55. [CrossRef]

67. Levett, P.A.; Melchels, F.P.W.; Schrobback, K.; Hutmacher, D.W.; Malda, J.; Klein, T.J. A biomimetic extracellular matrix for cartilage tissue engineering centered on photocurable gelatin, hyaluronic acid and chondroitin sulfate. Acta Biomater. 2014, 10, 214-223. [CrossRef] [PubMed]

68. Wu, W.; DeConinck, A.; Lewis, J.A. Omnidirectional printing of 3D microvascular networks. Adv. Mater. 2011, 23, 178-183. [CrossRef] [PubMed]

69. Kolesky, D.B.; Homan, K.A.; Skylar-Scott, M.A.; Lewis, J.A. Three-dimensional bioprinting of thick vascularized tissues. Proc. Natl. Acad. Sci. USA 2016, 113, 3179-3184. [CrossRef] [PubMed]

70. Hinton, T.J.; Hudson, A.; Pusch, K.; Lee, A.; Feinberg, A.W. 3D Printing PDMS Elastomer in a Hydrophilic Support Bath via Freeform Reversible Embedding. ACS Biomater. Sci. Eng. 2016, 2, 1781-1786. [CrossRef] [PubMed]

71. O'Bryan, C.S.; Bhattacharjee, T.; Hart, S.; Kabb, C.P.; Schulze, K.D.; Chilakala, I.; Sumerlin, B.S.; Sawyer, W.G.; Angelini, T.E. Self-assembled micro-organogels for 3D printing silicone structures. Sci. Adv. 2017, 3, e1602800. [CrossRef] [PubMed]

72. Kang, H.-W.W.; Lee, S.J.; Ko, I.K.; Kengla, C.; Yoo, J.J.; Atala, A. A 3D bioprinting system to produce human-scale tissue constructs with structural integrity. Nat. Biotechnol. 2016, 34, 312-319. [CrossRef] [PubMed]

73. Visser, J.; Melchels, F.P.W.; Jeon, J.E.; Van Bussel, E.M.; Kimpton, L.S.; Byrne, H.M.; Dhert, W.J.A.; Dalton, P.D.; Hutmacher, D.W.; Malda, J. Reinforcement of hydrogels using three-dimensionally printed microfibres. Nat. Commun. 2015, 6, 6933. [CrossRef] [PubMed]

74. DeSimone, J.M.; Barth, F.M.; Oh, H.J.; Loo, W.S.; Wilson, M.W.; Hetts, S.W.; Parkinson, D.Y.; Maslyn, J.A.; Robbins, G.R.; Yee, C.R.; et al. 3D Printed Absorber for Capturing Chemotherapy Drugs before They Spread through the Body. ACS Cent. Sci. 2019, 5, 419-427. 
75. Moroni, L.; Boland, T.; Burdick, J.A.; De Maria, C.; Derby, B.; Forgacs, G.; Groll, J.; Li, Q.; Malda, J.; Mironov, V.A.; et al. Biofabrication: A Guide to Technology and Terminology. Trends Biotechnol. 2018, 36, 384-402. [CrossRef]

76. Mandal, S.; Meininger, S.; Gbureck, U.; Basu, B. 3D powder printed tetracalcium phosphate scaffold with phytic acid binder: Fabrication, microstructure and in situ X-Ray tomography analysis of compressive failure. J. Mater. Sci. Mater. Med. 2018, 29, 29. [CrossRef]

77. Nyberg, E.; Rindone, A.; Dorafshar, A.; Grayson, W.L. Comparison of 3D-Printed Poly-varepsilon-Caprolactone Scaffolds Functionalized with Tricalcium Phosphate, Hydroxyapatite, Bio-Oss, or Decellularized Bone Matrix. Tissue Eng. Part. A 2017, 23, 503-514. [CrossRef]

78. Cox, S.C.; Jamshidi, P.; Eisenstein, N.M.; Webber, M.A.; Hassanin, H.; Attallah, M.M.; Shepherd, D.E.T.; Addison, O.; Grover, L.M. Adding functionality with additive manufacturing: Fabrication of titanium-based antibiotic eluting implants. Mater. Sci. Eng. C Mater. Biol. Appl. 2016, 64, 407-415. [CrossRef] [PubMed]

79. Chocholata, P.; Kulda, V.; Babuska, V. Fabrication of Scaffolds for Bone-Tissue Regeneration. Materials 2019, 12, 568. [CrossRef] [PubMed]

80. Zhu, L.Y.; Li, L.; Shi, J.P.; Li, Z.A.; Yang, J.Q. Mechanical characterization of 3D printed multi-morphology porous Ti6Al4V scaffolds based on triply periodic minimal surface architectures. Am. J. Transl. Res. 2018, 10, 3443-3454.

81. Ma, Y.; Hu, N.; Liu, J.; Zhai, X.; Wu, M.; Hu, C.; Li, L.; Lai, Y.; Pan, H.; Lu, W.W.; et al. Three-Dimensional Printing of Biodegradable Piperazine-Based Polyurethane-Urea Scaffolds with Enhanced Osteogenesis for Bone Regeneration. ACS Appl. Mater. Interfaces 2019, 11, 9. [CrossRef] [PubMed]

82. Zhao, H.; Chen, Y.; Shao, L.; Xie, M.; Nie, J.; Qiu, J.; Zhao, P.; Ramezani, H.; Fu, J.; Ouyang, H.; et al. Airflow-Assisted 3D Bioprinting of Human Heterogeneous Microspheroidal Organoids with Microfluidic Nozzle. Small 2018, 14, e1802630. [CrossRef] [PubMed]

83. Riedl, A.; Schlederer, M.; Pudelko, K.; Stadler, M.; Walter, S.; Unterleuthner, D.; Unger, C.; Kramer, N.; Hengstschläger, M.; Kenner, L.; et al. Comparison of cancer cells in 2D vs 3D culture reveals differences in AKT-mTOR-S6K signaling and drug responses. J. Cell Sci. 2017, 130, 203-218. [CrossRef] [PubMed]

84. Mathews Griner, L.A.; Zhang, X.; Guha, R.; McKnight, C.; Goldlust, I.S.; Lal-Nag, M.; Wilson, K.; Michael, S.; Titus, S.; Shinn, P.; et al. Large-scale pharmacological profiling of 3D tumor models of cancer cells. Cell Death Dis. 2016, 7, e2492. [CrossRef]

85. Theodoraki, M.A.; Rezende, C.O.; Chantarasriwong, O., Jr.; Corben, A.D.; Theodorakis, E.A.; Alpaugh, M.L. Spontaneously-forming spheroids as an in vitro cancer cell model for anticancer drug screening. Oncotarget 2015, 6, 21255-21267. [CrossRef]

86. Nath, S.; Devi, G.R. Three-dimensional culture systems in cancer research: Focus on tumor spheroid model. Pharmacol. Ther. 2016, 163, 94-108. [CrossRef]

87. Kim, Y.; Kang, K.; Yoon, S.; Kim, J.S.; Park, S.A.; Kim, W.D.; Lee, S.B.; Ryu, K.Y.; Jeong, J.; Choi, D. Prolongation of liver-specific function for primary hepatocytes maintenance in 3D printed architectures. Organogenesis 2018, 14, 1-12. [CrossRef]

88. Cui, H.; Nowicki, M.; Fisher, J.P.; Zhang, L.G. 3D Bioprinting for Organ Regeneration. Adv. Healthc. Mater. 2017, 6, 1601118. [CrossRef] [PubMed]

89. Schwank, G.; Koo, B.K.; Sasselli, V.; Dekkers, J.F.; Heo, I.; Demircan, T.; Sasaki, N.; Boymans, S.; Cuppen, E.; van der Ent, C.K.; et al. Functional repair of CFTR by CRISPR/Cas9 in intestinal stem cell organoids of cystic fibrosis patients. Cell Stem Cell 2013, 13, 653-658. Cell Stem Cell 2013, 13, 653-658. [CrossRef] [PubMed]

90. Lei, M.; Schumacher, L.J.; Lai, Y.C.; Juan, W.T.; Yeh, C.Y.; Wu, P.; Jiang, T.X.; Baker, R.E.; Widelitz, R.B.; Yang, L.; et al. Self-organization process in newborn skin organoid formation inspires strategy to restore hair regeneration of adult cells. Proc. Natl. Acad. Sci. USA 2017, 114, E7101-E7110. [CrossRef] [PubMed]

91. Lancaster, M.A.; Knoblich, J.A. Organogenesis in a dish: Modeling development and disease using organoid technologies. Science 2014, 345, 1247125. [CrossRef] [PubMed]

92. Yin, X.; Mead, B.E.; Safaee, H.; Langer, R.; Karp, J.M.; Levy, O. Engineering Stem Cell Organoids. Cell Stem Cell 2016, 18, 25-38. [CrossRef] [PubMed]

93. Pourchet, L.J.; Thepot, A.; Albouy, M.; Courtial, E.J.; Boher, A.; Blum, L.J.; Marquette, C.A. Human Skin 3D Bioprinting Using Scaffold-Free Approach. Adv. Healthc. Mater. 2017, 6, 1601101. [CrossRef] 
94. Grix, T.; Ruppelt, A.; Thomas, A.; Amler, A.K.; Noichl, B.P.; Lauster, R.; Kloke, L. Bioprinting Perfusion-Enabled Liver Equivalents for Advanced Organ-on-a-Chip Applications. Genes 2018, 9, 176. [CrossRef]

95. Bulanova, E.A.; Koudan, E.V.; Degosserie, J.; Heymans, C.; Pereira, F.D.; Parfenov, V.A.; Sun, Y.; Wang, Q.; Akhmedova, S.A.; Sviridova, I.K.; et al. Bioprinting of a functional vascularized mouse thyroid gland construct. Biofabrication 2017, 9, 034105. [CrossRef]

96. Skardal, A.; Devarasetty, M.; Kang, H.W.; Seol, Y.J.; Forsythe, S.D.; Bishop, C.; Shupe, T.; Soker, S.; Atala, A. Bioprinting Cellularized Constructs Using a Tissue-specific Hydrogel Bioink. J. Vis. Exp. 2016, e53606. [CrossRef]

97. Reid, J.A.; Mollica, P.A.; Bruno, R.D.; Sachs, P.C. Consistent and reproducible cultures of large-scale 3D mammary epithelial structures using an accessible bioprinting platform. Breast Cancer Res. 2018, 20, 122. [CrossRef]

98. Zhang, Y.S.; Arneri, A.; Bersini, S.; Shin, S.R.; Zhu, K.; Goli-Malekabadi, Z.; Aleman, J.; Colosi, C.; Busignani, F.; Dell'Erba, V.; et al. Bioprinting 3D microfibrous scaffolds for engineering endothelialized myocardium and heart-on-a-chip. Biomaterials 2016, 110, 45-59. [CrossRef] [PubMed]

99. Lee, W.; Pinckney, J.; Lee, V.; Lee, J.H.; Fischer, K.; Polio, S.; Park, J.K.; Yoo, S.S. Three-dimensional bioprinting of rat embryonic neural cells. Neuroreport 2009, 20, 798-803. [CrossRef] [PubMed]

100. Dai, X.; Liu, L.; Ouyang, J.; Li, X.; Zhang, X.; Lan, Q.; Xu, T. Coaxial 3D bioprinting of self-assembled multicellular heterogeneous tumor fibers. Sci. Rep. 2017, 7, 1457. [CrossRef]

101. Knowlton, S.; Tasoglu, S. A Bioprinted Liver-on-a-Chip for Drug Screening Applications. Trends Biotechnol. 2016, 34, 681-682. [CrossRef] [PubMed]

102. Kizawa, H.; Nagao, E.; Shimamura, M.; Zhang, G.; Torii, H. Scaffold-free 3D bio-printed human liver tissue stably maintains metabolic functions useful for drug discovery. Biochem. Biophys. Rep. 2017, 10, 186-191. [CrossRef] [PubMed]

103. Yang, Y.; Du, T.; Zhang, J.; Kang, T.; Luo, L.; Tao, J.; Gou, Z.; Chen, S.; Du, Y.; He, J.; et al. A 3D-Engineered Conformal Implant Releases DNA Nanocomplexs for Eradicating the Postsurgery Residual Glioblastoma. Adv. Sci. 2017, 4, 1600491. [CrossRef] [PubMed]

104. Osidak, E.O.; Karalkin, P.A.; Osidak, M.S.; Parfenov, V.A.; Sivogrivov, D.E.; Pereira, F.; Gryadunova, A.A.; Koudan, E.V.; Khesuani, Y.D.; Kasyanov, V.A.; et al. Viscoll collagen solution as a novel bioink for direct 3D bioprinting. J. Mater. Sci. Mater. Med. 2019, 30, 31. [CrossRef] [PubMed]

105. He, Y.; Yang, F.; Zhao, H.; Gao, Q.; Xia, B.; Fu, J. Research on the printability of hydrogels in 3D bioprinting. Sci. Rep. 2016, 6, 29977. [CrossRef]

106. Vignesh, U.; Mehrotra, D.; Vaibhav Anand, D.; Howlader, D. Three dimensional reconstruction of late post traumatic orbital wall defects by customized implants using CAD-CAM, 3D stereolithographic models: A case report. J. Oral Biol. Craniofacial Res. 2017, 7, 212-218.

107. Shim, J.H.; Won, J.Y.; Park, J.H.; Bae, J.H.; Ahn, G.; Kim, C.H.; Lim, D.H.; Cho, D.W.; Yun, W.S.; Bae, E.B.; et al. Effects of 3D-Printed Polycaprolactone/beta-Tricalcium Phosphate Membranes on Guided Bone Regeneration. Int. J. Mol. Sci. 2017, 18, 899. [CrossRef]

108. Shao, H.; Ke, X.; Liu, A.; Sun, M.; He, Y.; Yang, X.; Fu, J.; Liu, Y.; Zhang, L.; Yang, G.; et al. Bone regeneration in $3 \mathrm{D}$ printing bioactive ceramic scaffolds with improved tissue/material interface pore architecture in thin-wall bone defect. Biofabrication 2017, 9, 025003. [CrossRef] [PubMed]

109. Zhang, W.; Feng, C.; Yang, G.; Li, G.; Ding, X.; Wang, S.; Dou, Y.; Zhang, Z.; Chang, J.; Wu, C.; et al. 3D-printed scaffolds with synergistic effect of hollow-pipe structure and bioactive ions for vascularized bone regeneration. Biomaterials 2017, 135, 85-95. [CrossRef]

110. Nauth, A.; Schemitsch, E.; Norris, B.; Nollin, Z.; Watson, J.T. Critical-Size Bone Defects: Is There a Consensus for Diagnosis and Treatment? J. Orthop. Trauma 2018, 32 (Suppl. 1), S7-S11. [CrossRef]

111. Kaempfen, A.; Todorov, A.; Guven, S.; Largo, R.D.; Jaquiery, C.; Scherberich, A.; Martin, I.; Schaefer, D.J. Engraftment of Prevascularized, Tissue Engineered Constructs in a Novel Rabbit Segmental Bone Defect Model. Int. J. Mol. Sci. 2015, 16, 12616-12630. [CrossRef] [PubMed]

112. Deng, Y.; Jiang, C.; Li, C.; Li, T.; Peng, M.; Wang, J.; Dai, K. 3D printed scaffolds of calcium silicate-doped beta-TCP synergize with co-cultured endothelial and stromal cells to promote vascularization and bone formation. Sci. Rep. 2017, 7, 5588. [CrossRef] 
113. Wen, Y.; Xun, S.; Haoye, M.; Baichuan, S.; Peng, C.; Xuejian, L.; Kaihong, Z.; Xuan, Y.; Jiang, P.; Shibi, L. 3D printed porous ceramic scaffolds for bone tissue engineering: A review. Biomater. Sci. 2017, 5, 1690-1698. [CrossRef] [PubMed]

114. Lee, C.H.; Cook, J.L.; Mendelson, A.; Moioli, E.K.; Yao, H.; Mao, J.J. Regeneration of the articular surface of the rabbit synovial joint by cell homing: A proof of concept study. Lancet 2010, 376, 440-448. [CrossRef]

115. Chang, J.W.; Park, S.A.; Park, J.K.; Choi, J.W.; Kim, Y.S.; Shin, Y.S.; Kim, C.H. Tissue-engineered tracheal reconstruction using three-dimensionally printed artificial tracheal graft: Preliminary report. Artif. Organs 2014, 38, E95-E105. [CrossRef] [PubMed]

116. Lee, C.H.; Hajibandeh, J.; Suzuki, T.; Fan, A.; Shang, P.; Mao, J.J. Three-dimensional printed multiphase scaffolds for regeneration of periodontium complex. Tissue Eng. Part A 2014, 20, 1342-1351. [CrossRef] [PubMed]

117. Zhang, Q.H.; Cossey, A.; Tong, J. Stress shielding in periprosthetic bone following a total knee replacement: Effects of implant material, design and alignment. Med. Eng. Phys. 2016, 38, 1481-1488. [CrossRef]

118. MacBarb, R.F.; Lindsey, D.P.; Bahney, C.S.; Woods, S.A.; Wolfe, M.L.; Yerby, S.A. Fortifying the Bone-Implant Interface Part 1: An In Vitro Evaluation of 3D-Printed and TPS Porous Surfaces. Int. J. Spine Surg. 2017, 11, 15. [CrossRef]

119. Petrie, T.A.; Raynor, J.E.; Reyes, C.D.; Burns, K.L.; Collard, D.M.; Garcia, A.J. The effect of integrin-specific bioactive coatings on tissue healing and implant osseointegration. Biomaterials 2008, 29, 2849-2857. [CrossRef] [PubMed]

120. Tran, P.A.; Sarin, L.; Hurt, R.H.; Webster, T.J. Titanium surfaces with adherent selenium nanoclusters as a novel anticancer orthopedic material. J. Biomed. Mater. Res. A 2010, 93, 1417-1428. [CrossRef] [PubMed]

121. Kazzazi, S.M.; Kranioti, E.F. Applicability of 3D-dental reconstruction in cervical odontometrics. Am. J. Phys. Anthr. 2018, 165, 370-377. [CrossRef]

122. Wang, Y.; Wu, L.; Guo, H.; Qiu, T.; Huang, Y.; Lin, B.; Wang, L. Computation of tooth axes of existent and missing teeth from 3D CT images. Biomed. Eng. 2015, 60, 623-632. [CrossRef] [PubMed]

123. Oberoi, G.; Nitsch, S.; Edelmayer, M.; Janjic, K.; Muller, A.S.; Agis, H. 3D Printing-Encompassing the Facets of Dentistry. Front. Bioeng. Biotechnol. 2018, 6, 172. [CrossRef] [PubMed]

124. Tahayeri, A.; Morgan, M.; Fugolin, A.P.; Bompolaki, D.; Athirasala, A.; Pfeifer, C.S.; Ferracane, J.L.; Bertassoni, L.E. 3D printed versus conventionally cured provisional crown and bridge dental materials. Dent. Mater. 2018, 34, 192-200. [CrossRef]

125. Alharbi, N.; Wismeijer, D.; Osman, R.B. Additive Manufacturing Techniques in Prosthodontics: Where Do We Currently Stand? A Critical Review. Int. J. Prosthodont. 2017, 30, 474-484. [CrossRef]

126. Gan, N.; Ruan, Y.; Sun, J.; Xiong, Y.; Jiao, T. Comparison of Adaptation between the Major Connectors Fabricated from Intraoral Digital Impressions and Extraoral Digital Impressions. Sci. Rep. 2018, 8, 529. [CrossRef] [PubMed]

127. Martorelli, M.; Gerbino, S.; Giudice, M.; Ausiello, P. A comparison between customized clear and removable orthodontic appliances manufactured using RP and CNC techniques. Dent. Mater. 2013, 29, e1-e10. [CrossRef]

128. Hixon, K.R.; Melvin, A.M.; Lin, A.Y.; Hall, A.F.; Sell, S.A. Cryogel scaffolds from patient-specific 3D-printed molds for personalized tissue-engineered bone regeneration in pediatric cleft-craniofacial defects. J. Biomater. Appl. 2017, 32, 598-611. [CrossRef]

129. Haglin, J.M.; Eltorai, A.E.; Gil, J.A.; Marcaccio, S.E.; Botero-Hincapie, J.; Daniels, A.H. Patient-Specific Orthopaedic Implants. Orthop. Surg. 2016, 8, 417-424. [CrossRef] [PubMed]

130. Chang, B.; Song, W.; Han, T.; Yan, J.; Li, F.; Zhao, L.; Kou, H.; Zhang, Y. Influence of pore size of porous titanium fabricated by vacuum diffusion bonding of titanium meshes on cell penetration and bone ingrowth. Acta Biomater. 2016, 33, 311-321. [CrossRef]

131. Barba, A.; Diez-Escudero, A.; Maazouz, Y.; Rappe, K.; Espanol, M.; Montufar, E.B.; Bonany, M.; Sadowska, J.M.; Guillem-Marti, J.; Ohman-Magi, C.; et al. Osteoinduction by Foamed and 3D-Printed Calcium Phosphate Scaffolds: Effect of Nanostructure and Pore Architecture. ACS Appl. Mater. Interfaces 2017, 9, 41722-41736. [CrossRef] [PubMed]

132. Trombetta, R.; Inzana, J.A.; Schwarz, E.M.; Kates, S.L.; Awad, H.A. 3D Printing of Calcium Phosphate Ceramics for Bone Tissue Engineering and Drug Delivery. Ann. Biomed. Eng. 2017, 45, 23-44. [CrossRef] 
133. Cipitria, A.; Reichert, J.C.; Epari, D.R.; Saifzadeh, S.; Berner, A.; Schell, H.; Mehta, M.; Schuetz, M.A.; Duda, G.N.; Hutmacher, D.W. Polycaprolactone scaffold and reduced rhBMP-7 dose for the regeneration of critical-sized defects in sheep tibiae. Biomaterials 2013, 34, 9960-9968. [CrossRef]

134. Fitzpatrick, P.A. Design of a Patient Specific, 3D printed Arm Cast. KNE Eng. 2017, 2, 135. [CrossRef]

135. Gioumouxouzis, C.I.; Karavasili, C.; Fatouros, D.G. Recent advances in pharmaceutical dosage forms and devices using additive manufacturing technologies. Drug Discov. Today 2018, 24, 636-643. [CrossRef]

136. Anbalagan, P.; Heng, P.W.S.; Liew, C.V. Tablet compression tooling_Impact of punch face edge modification. Int. J. Pharm. 2017, 524, 373-381. [CrossRef]

137. Sadia, M.; Arafat, B.; Ahmed, W.; Forbes, R.T.; Alhnan, M.A. Channelled tablets: An innovative approach to accelerating drug release from 3D printed tablets. J. Control. Release 2018, 269, 355-363. [CrossRef]

138. Solanki, N.G.; Tahsin, M.; Shah, A.V.; Serajuddin, A.T.M. Formulation of 3D Printed Tablet for Rapid Drug Release by Fused Deposition Modeling: Screening Polymers for Drug Release, Drug-Polymer Miscibility and Printability. J. Pharm. Sci. 2018, 107, 390-401. [CrossRef]

139. Martinez, P.R.; Goyanes, A.; Basit, A.W.; Gaisford, S. Influence of Geometry on the Drug Release Profiles of Stereolithographic (SLA) 3D-Printed Tablets. AAPS PharmSciTech 2018, 19, 3355-3361. [CrossRef]

140. Clark, E.A.; Alexander, M.R.; Irvine, D.J.; Roberts, C.J.; Wallace, M.J.; Sharpe, S.; Yoo, J.; Hague, R.J.M.; Tuck, C.J.; Wildman, R.D. 3D printing of tablets using inkjet with UV photoinitiation. Int. J. Pharm. 2017, 529, 523-530. [CrossRef]

141. Khaled, S.A.; Burley, J.C.; Alexander, M.R.; Yang, J.; Roberts, C.J. 3D printing of tablets containing multiple drugs with defined release profiles. Int. J. Pharm. 2015, 494, 643-650. [CrossRef]

142. Terada, T.; Noda, S.; Inui, K. Management of dose variability and side effects for individualized cancer pharmacotherapy with tyrosine kinase inhibitors. Pharmacol. Ther. 2015, 152, 125-134. [CrossRef]

143. Solhaug, V.; Molden, E. Individual variability in clinical effect and tolerability of opioid analgesics-Importance of drug interactions and pharmacogenetics. Scand. J. Pain 2017, 17, 193-200. [CrossRef]

144. Osouli-Bostanabad, K.; Adibkia, K. Made-on-demand, complex and personalized 3D-printed drug products. Bioimpacts 2018, 8, 77-79. [CrossRef]

145. Pastore, M.N.; Kalia, Y.N.; Horstmann, M.; Roberts, M.S. Transdermal patches: History, development and pharmacology. Br. J. Pharm. 2015, 172, 2179-2209. [CrossRef]

146. Economidou, S.N.; Lamprou, D.A.; Douroumis, D. 3D printing applications for transdermal drug delivery. Int. J. Pharm. 2018, 544, 415-424. [CrossRef]

147. Pere, C.P.P.; Economidou, S.N.; Lall, G.; Ziraud, C.; Boateng, J.S.; Alexander, B.D.; Lamprou, D.A.; Douroumis, D. 3D printed microneedles for insulin skin delivery. Int. J. Pharm. 2018, 544, 425-432. [CrossRef]

148. Haj-Ahmad, R.; Khan, H.; Arshad, M.S.; Rasekh, M.; Hussain, A.; Walsh, S.; Li, X.; Chang, M.W.; Ahmad, Z. Microneedle Coating Techniques for Transdermal Drug Delivery. Pharmaceutics 2015, 7, 486-502. [CrossRef] [PubMed]

149. Dayyoub, E.; Frant, M.; Pinnapireddy, S.R.; Liefeith, K.; Bakowsky, U. Antibacterial and anti-encrustation biodegradable polymer coating for urinary catheter. Int. J. Pharm. 2017, 531, 205-214. [CrossRef] [PubMed]

150. Weisman, J.A.; Ballard, D.H.; Jammalamadaka, U.; Tappa, K.; Sumerel, J.; D'Agostino, H.B.; Mills, D.K.; Woodard, P.K. 3D Printed Antibiotic and Chemotherapeutic Eluting Catheters for Potential Use in Interventional Radiology: In Vitro Proof of Concept Study. Acad. Radiol. 2019, 26, 270-274. [CrossRef] [PubMed]

151. Sandler, N.; Salmela, I.; Fallarero, A.; Rosling, A.; Khajeheian, M.; Kolakovic, R.; Genina, N.; Nyman, J.; Vuorela, P. Towards fabrication of 3D printed medical devices to prevent biofilm formation. Int. J. Pharm. 2014, 459, 62-64. [CrossRef]

152. George, M.; Aroom, K.R.; Hawes, H.G.; Gill, B.S.; Love, J. 3D Printed Surgical Instruments: The Design and Fabrication Process. World J. Surg. 2017, 41, 314-319. [CrossRef] [PubMed]

153. Liu, K.; Zhang, Q.; Li, X.; Zhao, C.; Quan, X.; Zhao, R.; Chen, Z.; Li, Y. Preliminary application of a multi-level 3D printing drill guide template for pedicle screw placement in severe and rigid scoliosis. Eur. Spine J. 2017, 26, 1684-1689. [CrossRef]

154. Guo, F.; Dai, J.; Zhang, J.; Ma, Y.; Zhu, G.; Shen, J.; Niu, G. Individualized 3D printing navigation template for pedicle screw fixation in upper cervical spine. PLoS ONE 2017, 12, e0171509. [CrossRef] [PubMed] 
155. Rankin, T.M.; Giovinco, N.A.; Cucher, D.J.; Watts, G.; Hurwitz, B.; Armstrong, D.G. Three-dimensional printing surgical instruments: Are we there yet? J. Surg. Res. 2014, 189, 193-197. [CrossRef] [PubMed]

156. Wong, J.Y.; Pfahnl, A.C. 3D Printed Surgical Instruments Evaluated by a Simulated Crew of a Mars Mission. Aerosp Med. Hum. Perform. 2016, 87, 806-810. [CrossRef]

157. Wong, J.Y.; Pfahnl, A.C. 3D printing of surgical instruments for long-duration space missions. Aviat Space Env. Med. 2014, 85, 758-763. [CrossRef]

158. Singhal, A.J.; Shetty, V.; Bhagavan, K.R.; Ragothaman, A.; Shetty, V.; Koneru, G.; Agarwala, M. Improved Surgery Planning Using 3-D Printing: A Case Study. Indian J. Surg. 2016, 78, 100-104. [CrossRef] [PubMed]

159. Wu, X.B.; Wang, J.Q.; Zhao, C.P.; Sun, X.; Shi, Y.; Zhang, Z.A.; Li, Y.N.; Wang, M.Y. Printed three-dimensional anatomic templates for virtual preoperative planning before reconstruction of old pelvic injuries: Initial results. Chin. Med. J. 2015, 128, 477-482. [CrossRef]

160. Cherkasskiy, L.; Caffrey, J.P.; Szewczyk, A.F.; Cory, E.; Bomar, J.D.; Farnsworth, C.L.; Jeffords, M.; Wenger, D.R.; Sah, R.L.; Upasani, V.V. Patient-specific 3D models aid planning for triplane proximal femoral osteotomy in slipped capital femoral epiphysis. J. Child. Orthop. 2017, 11, 147-153. [CrossRef] [PubMed]

161. Jones, R.; Haufe, P.; Sells, E.; Iravani, P.; Olliver, V.; Palmer, C.; Bowyer, A. RepRap-The replicating rapid prototyper. Robotica 2011, 29, 177-191. [CrossRef]

162. Hinton, T.J.; Jallerat, Q.; Palchesko, R.N.; Park,J.H.; Grodzicki, M.S.; Shue, H.-J.; Ramadan, M.H.; Hudson, A.R.; Feinberg, A.W. Three-dimensional printing of complex biological structures by freeform reversible embedding of suspended hydrogels. Sci. Adv. 2015, 1, e1500758. [CrossRef]

163. Feinberg, A.W.; Miller, J.S. Progress in three-dimensional bioprinting. MRS Bull. 2017, 42, 557-562. [CrossRef]

164. Pusch, K.; Hinton, T.J.; Feinberg, A.W. Large volume syringe pump extruder for desktop 3D printers. HardwareX 2018, 3, 49-61. [CrossRef]

165. Livesu, M.; Csiszer, M.; Mehes, E.; Czirok, A. Software tools for cell culture-related 3D printed structures. PLOS ONE 2018, 13, e0203203.

(C) 2019 by the authors. Licensee MDPI, Basel, Switzerland. This article is an open access article distributed under the terms and conditions of the Creative Commons Attribution (CC BY) license (http://creativecommons.org/licenses/by/4.0/). 